\title{
Ionic partition diagram of tetraphenylporphyrin at the water|1,2-dichloroethane interface
}

\author{
Raheleh Partovi Nia ${ }^{a}$, Bin Su ${ }^{\mathrm{a}, 1}$, Manuel A. Méndez ${ }^{\mathrm{a}}$, Jean-Michel Barbe ${ }^{\mathrm{b}}$, Zdeněk Samec ${ }^{\mathrm{c}}$, \\ Hubert H. Girault ${ }^{\mathrm{a}, *}$ \\ a Laboratoire d'Electrochimie Physique et Analytique, Ecole Polytechnique Fédérale de Lausanne, Station 6, CH-1015 Lausanne, Switzerland \\ ${ }^{\mathrm{b}}$ Institut de Chimie Moléculaire de l'Université de Bourgogne, ICMUB (UMR 5260 du CNRS), 9 Avenue Alain Savary, BP 47870, 21078 Dijon Cedex, France \\ ' J. Heyrovsky Institute of Physical Chemistry of ASCR, v.v.i, Dolejskova 3, 18223 Prague 8, Czech Republic
}

\section{A R T I C L E I N F O}

\section{Article history:}

Received 12 October 2010

Received in revised form 30 November 2010

Accepted 1 December 2010

Available online 25 December 2010

\section{Keywords:}

Porphyrin

Free-base

Ionic partition diagram

Voltammetry

\begin{abstract}
A B S T R A C T
From the thermodynamic data obtained by ion-transfer voltammetry, we derive here the ionic partition diagram of 5,10,15,20-tetraphenyl-21H,23H-porphine ( $\left.\mathrm{H}_{2} \mathrm{TPP}\right)$ at the water|1,2-dichloroethane interface using a simple Born solvation model. This zone diagram shows under which form this porphyrin is present, i.e. neutral, monoprotonated or diprotonated, and in which phase i.e. either in the aqueous or the organic phase as a function of the aqueous $\mathrm{pH}$ and the interface polarisation that can be controlled externally or by the distribution of supporting electrolytes. This diagram explains why the monoprotonated form has been difficult to observe when doing biphasic $\mathrm{pH}$ titrations.
\end{abstract}

(c) 2010 Elsevier B.V. All rights reserved.

\section{Introduction}

Protonation of the porphyrin macrocycle has been extensively studied $[1,2]$. Indeed, diprotonation of the porphyrin core has important effects on the static and dynamic photophysical properties when compared to their free-base parents. Some of these effects stems from increased symmetry, and are similar to those observed upon metalation. Additionally, relative to the parent free-bases, the diacids yield broadened optical bands, and increased separation between absorption and emission maxima. All these effects are in particular enhanced in diacids as that of the free-base 5,10,15,20-meso-tetraphenylporphyrin ( $\left.\mathrm{H}_{2} \mathrm{TPP}\right)$ [3].

Upon protonation of the free-base porphyrins, the symmetry changes from $\mathrm{D}_{2} \mathrm{~h}$ to $\mathrm{D}_{4} \mathrm{~h}$. Indeed, porphyrin diacids have non-planar structures with mainly saddle-type distortions of the porphyrin ring, as revealed by X-ray crystallography [4-7]. Deviations from planarity for diacids bearing meso-phenyl rings, such as $\mathrm{H}_{2}$ TPP diacids, approach in magnitude those obtained in peripherally crowded porphyrins, such as free-base octaethyltetraphenylporphyrin $\left(\mathrm{H}_{2} \mathrm{OEP}\right)$ [8], dodecaphenylporphyrin $\left(\mathrm{H}_{2} \mathrm{DPP}\right)$ [9]. The porphyrin diacids are usually the chromophore of the protonated form and monocations can only be obtained under special experi-

\footnotetext{
* Corresponding author. Fax: +41216933667.

E-mail address: hubert.girault@epfl.ch (H.H. Girault).

1 Present address: Institute of Microanalytical Systems, Department of Chemistry, Zhejiang University, 310058 Hangzhou, China.
}

mental conditions. Corwin et al. have reported the protonation of porphyrin observing four, three, and two $\mathrm{Q}$ bands for the free-base, monoprotonated and diprotonated porphyrins, respectively [10].

On the other hand, voltammetry at liquid|liquid interfaces has proved to be a very useful tool to study the interfacial protonation of lipophilic molecules as pioneered by Hofmanova et al. [11] Over the last two decades, the transfer of $\mathrm{H}^{+}$ion facilitated by ion carriers or basic extractants has been studied extensively [12-15]. Homolka et al. investigated proton transfer across the water|nitrobenzene $(\mathrm{W} \mid \mathrm{NB})$ interface assisted by a series of amines with an aromatic ring, discussed the dependence of the transfer process on the structure of the proton acceptors and obtained the kinetic and thermodynamic parameters of the process [16]. Additionally, the transfer mechanism of protonated 1,10-phenanthroline and its derivatives between the aqueous phase and 1,2-dichloroethane (1,2-DCE) phase was elucidated by Yoshida and Freiser using current scanning polarography at an ascending water electrode [14]. The transfer behaviour of protonated acridine across the W|NB interface has been studied by Liu and Wang [15] using chronopotentiometry with linear current scanning, polarography with the electrolyte dropping electrode [17,18] and cyclic voltammetry $[19,20]$. Ion-transfer voltammetry at the ITIES has now become a well-established method to study the acid-base properties of molecules dissolved in an organic phase in contact with an aqueous electrolyte. As shown by Reymond et al. for the study of therapeutic molecules, this methodology allows the determination of acidity constant and ultimately the formulation of the so-called io- 
nic partition diagrams [21-24]. The transfer behaviour of $\mathrm{H}^{+}$ion facilitated by porphyrins has been reported previously at the W|NB interface by Xia et al. [25] and by Osakai and Muto [26]. The protonation of $\mathrm{H}_{2}$ TPP has been studied at the water|dodecane interface by Nagatani et al. using a two-phase stopped flow [27].

Recently, we have studied by ion-transfer voltammetry the successive protonation of $\mathrm{H}_{2}$ TPP $[28,29]$ and we were able to determine the acidity constants in the organic phase. In particular, we have evidenced the existence of the monoprotonated $\mathrm{H}_{3} \mathrm{TPP}^{+}$, which is otherwise elusive to observe. To determine the conditions where $\mathrm{H}_{3} \mathrm{TPP}^{+}$can be observed we present here a methodology to calculate the ionic partition diagram of $\mathrm{H}_{2}$ TPP based on the use of the Born solvation model to evaluate differences in Gibbs energies of solvation between the different protonation states.

\section{Experimental section}

\subsection{Chemicals}

All chemicals are analytical grade and used as received without further purification. Lithium chloride ( $\mathrm{LiCl},>99 \%)$, bis(triphenylphosphoranylidene)ammonium chloride ( $\mathrm{BACl},>98 \%$ ), tetramethylammonium chloride (TMACl, $>98.0 \%$ ), and 1,2-dichloroethane (1,2-DCE, $>99.8 \%)$ were bought from Fluka. Lithium tetrakis(pentafluorophenyl)-borate (LiTB) was provided by Boulder Scientific Company. Bis(triphenylphosphoranylidene)ammonium tetrakis (pentafluorophenyl)-borate (BATB) was prepared by metathesis of $\mathrm{BACl}$ and LiTB in a methanol/water $(V / V=2)$ mixture, followed by recrystallization in acetone. The aqueous solutions were prepared with ultrapure water from a Milli-Q system (Millipore Milli-Q185). No buffer was used not to introduce extra ions in the aqueous phase, and the solution $\mathrm{pH}$ was adjusted by addition of $\mathrm{HCl} . \mathrm{H}_{2}$ TPP was synthesized following the typical procedure [30].

\subsection{Electrochemical measurements}

The electrochemical experiments were performed on an Ivium Compact Stat in a four-electrode configuration by using a conventional glass cell with a cross section of $1.53 \mathrm{~cm}^{2}$. The electrolyte compositions of the cells are illustrated in Scheme 1. $\mathrm{LiCl}$ and BATB were employed as the aqueous and organic supporting electrolytes, respectively. The potential scale reported is referred to the Galvani potential difference obtained by correcting the applied potential with respect to the formal ion transfer potential of $\mathrm{TMA}^{+}$ $\left(\Delta_{\mathrm{o}}^{\mathrm{w}} \phi_{\mathrm{TMA}^{\prime}}^{0^{\prime}}=0.16 \mathrm{~V}\right)[31]$.

\section{Results and discussion}

As illustrated in Fig. 1, the presence of $\mathrm{H}_{2}$ TPP in the organic phase results in a double assisted proton transfer reaction. The first wave represents the transfer of a proton from water to 1,2-DCE facilitated by $\mathrm{H}_{2}$ TPP that in fact is the first protonation of $\mathrm{H}_{2}$ TPP to form the mono-acid $\mathrm{H}_{3} \mathrm{TPP}^{+}$in 1,2-DCE, and the second one rep-

\section{Cell 1}

$$
\mathrm{Ag}|\mathrm{AgCl}| \begin{array}{c|c||c|}
10 \mathrm{mM} \mathrm{LiCl}^{-} & 5 \mathrm{mM} \mathrm{BA}^{+} \mathrm{TB}^{-} \\
1 \mathrm{mM} \mathrm{BA}^{+} \mathrm{Cl}^{-} & x \mu \mathrm{M} \mathrm{H}_{2} \mathrm{TPP}
\end{array}|| \begin{gathered}
10 \mathrm{mM} \mathrm{LiCl} \\
100 \mathrm{mM} \mathrm{HCl}
\end{gathered}|\mathrm{AgCl}| \mathrm{Ag}
$$

Scheme 1. Composition of the electrochemical four electrode cell.

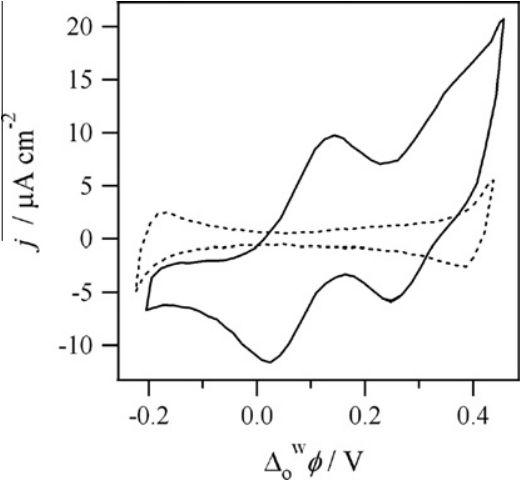

Fig. 1. Cyclic voltammogram using cell 1 with $x=0$ (dashed line) and $x=50$ (solid line) at $50 \mathrm{mV} \mathrm{s}^{-1}$.

resents the facilitated transfer of a second proton by $\mathrm{H}_{3} \mathrm{TPP}^{+}$. These two processes can be expressed as:

$\mathrm{H}_{2} \mathrm{TPP}_{\mathrm{DCE}}+\mathrm{H}_{\mathrm{W}}^{+} \rightleftarrows \mathrm{H}_{3} \mathrm{TPP}_{\mathrm{DCE}}^{+}$

$\mathrm{H}_{3} \mathrm{TPP}_{\mathrm{DCE}}^{+}+\mathrm{H}_{\mathrm{W}}^{+} \rightleftarrows \mathrm{H}_{4} \mathrm{TPP}_{\mathrm{DCE}}^{2+}$

To determine the apparent assisted ion transfer potential of $\mathrm{H}^{+}$, the scan rate dependence of the cyclic voltammetry together with the concentration dependence were extrapolated to zero scan rate and peak to peak separation of approximately $60 \mathrm{mV}$ was observed (see SI of [28]). The diffusion coefficient obtained from the scan rate and the concentration dependence were both found to be equal to $6.1 \times 10^{-5} \mathrm{~cm}^{2} \mathrm{~s}^{-1}$.

The facilitated transfer of $\mathrm{H}^{+}$in the presence of $\mathrm{H}_{2}$ TPP and $\mathrm{H}_{3} \mathrm{TPP}^{+}$is occurring at lower potentials than that of $\mathrm{H}^{+}$alone. In addition, considering the two processes are controlled by the diffusion of the porphyrin species in the organic phase, $K_{\mathrm{a} 1}$ and $K_{\mathrm{a} 2}$ the acidity constants of $\mathrm{H}_{4} \mathrm{TPP}^{2+}$ and $\mathrm{H}_{3} \mathrm{TPP}^{+}$, respectively, can be estimated by exploring the $\mathrm{pH}$ dependence presented in Fig. 2 of the apparent transfer potential of the second and first respectively according to equation [32]:

$\Delta_{\mathrm{o}}^{\mathrm{w}} \phi_{\mathrm{LH}^{+}}^{1 / 2}=\Delta_{\mathrm{o}}^{\mathrm{w}} \phi_{\mathrm{H}^{+}}^{0}+\frac{R T}{2 F} \ln \left(\frac{D_{\mathrm{L}}}{D_{\mathrm{LH}^{+}}}\right)-\frac{2.303 R T}{F} \mathrm{p} K_{\mathrm{a}}^{\mathrm{DCE}}+\frac{2.303 R T}{F} \mathrm{pH}^{w}$

where $\Delta_{\mathrm{o}}^{\mathrm{w}} \phi_{\mathrm{LH}^{+}}^{1 / 2}$ is the half-wave transfer potential of the respective facilitated proton transfers. $\Delta_{\mathrm{o}}^{\mathrm{w}} \phi_{\mathrm{H}^{+}}^{0}$ is the formal transfer potential for the transfer of $\mathrm{H}^{+}$. $D_{\mathrm{L}}$ and $D_{\mathrm{LH}}{ }^{+}\left(\mathrm{L}=\mathrm{H}_{2} \mathrm{TPP}, \mathrm{H}_{3} \mathrm{TPP}^{+}\right)$represent

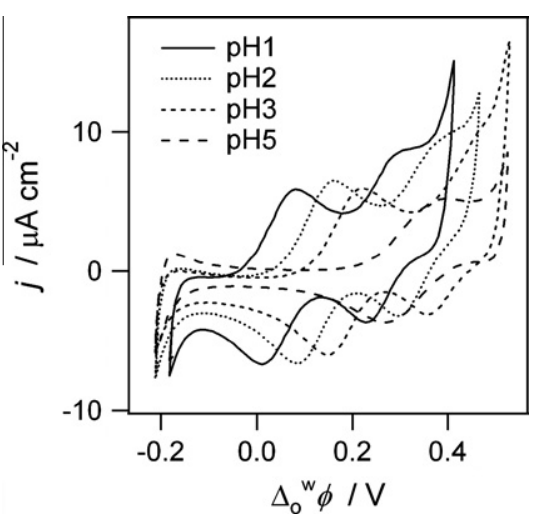

Fig. 2. Cyclic voltammograms in the presence of $\mathrm{H}_{2} \mathrm{TPP}($ Cell $1, x=50$ ) in 1,2-DCE at different $\mathrm{pH}$ values at a scan rate of $25 \mathrm{mV} \mathrm{s}^{-1}$. 
the diffusion coefficients of the proton acceptor ligand and its protonated form, and for simplicity it can be assumed that $D_{\mathrm{L}} \approx D_{\mathrm{LH}^{+}}$.

The relationship between $\Delta_{\mathrm{o}}^{\mathrm{w}} \phi$ and the $\mathrm{pH}^{\mathrm{w}}$ is found to be linear, and the intercept allows the determination of the $\mathrm{p} K_{\mathrm{a}}$ in the organic phase. As shown in Fig. 1 in Ref. [28] and as confirmed in the present study, $\mathrm{p} K_{\mathrm{a} 1}^{\mathrm{DCE}}$ and $\mathrm{p} K_{\mathrm{a} 2}^{\mathrm{DCE}}$ were found to be equal to 6.0 and 9.8 using $\mathrm{TB}^{-}$as the organic counter anion, and 6.7 and 10.3 when using $\mathrm{TPBCl}^{-}$as the organic counter anion [29] showing the influence of the organic supporting electrolyte in the basic properties of the porphyrin with

$K_{\mathrm{a}_{1}}^{\mathrm{DCE}}=\frac{a_{\mathrm{H}_{3} \mathrm{TPP}}^{\mathrm{DCE}} a_{\mathrm{H}^{+}}^{\mathrm{DCE}}}{a_{\mathrm{H}_{4} \mathrm{TPP}^{2+}}^{\mathrm{DCE}}}$

and

$K_{\mathrm{a}_{2}}^{\mathrm{DCE}}=\frac{a_{\mathrm{H}_{2} \mathrm{TPP}}^{\mathrm{DCE}} a_{\mathrm{H}^{+}}^{\mathrm{DCE}}}{a_{\mathrm{H}_{3} \mathrm{TPP}^{+}}^{\mathrm{DCE}}}$

Ionic partition diagrams have proved to be a rather useful representation of thermodynamic equilibria involving ionisable species in biphasic liquid systems [21-24]. The method consists in representing the domains of predominance of the various species as a function of applied potential and aqueous $\mathrm{pH}$. The construction of the partition diagram of an ionisable solute follows the well-known potential versus $\mathrm{pH}$ diagrams developed by Pourbaix [33].

\subsection{Ion transfer reactions}

As the boundary lines represent the locus where the concentrations of two contiguous species are equal, the Nernst equations for ion transfer reactions can be used directly to determine the evolution of the potential with $\mathrm{pH}$ for the partition of each ionic species between the two phases:

\section{Line for $\mathrm{H}_{3} \mathrm{TPP}_{\mathrm{W}}^{+} \rightleftarrows \mathrm{H}_{3} \mathrm{TPP}_{\mathrm{o}}^{+}$}

Although the monocation does not exist in water under normal experimental conditions, it is interesting to evaluate this theoretical borderline to gain access to the estimation of the second acidity constant $K_{\mathrm{a}_{2}}^{\mathrm{w}}$ in water. The Nernst equation for $\mathrm{H}_{3} \mathrm{TPP}^{+}$reads

$\Delta_{\mathrm{o}}^{\mathrm{w}} \phi=\Delta_{\mathrm{o}}^{\mathrm{w}} \phi_{\mathrm{H}_{3} \mathrm{TPP}^{+}}^{0}+\frac{R T}{F} \ln \left(\frac{a_{\mathrm{H}_{3} \mathrm{TPP}^{+}}^{\mathrm{o}}}{a_{\mathrm{H}_{3} \mathrm{TPP}^{+}}^{\mathrm{w}}}\right)$

where the superscripts " 0 " and " $w$ " stand for organic 1,2-DCE phase and water, respectively. The standard transfer potential of $\mathrm{H}_{3} \mathrm{TPP}^{+}$ can be calculated from the Nernst equation for proton transfer to give

$\Delta_{\mathrm{o}}^{\mathrm{w}} \phi_{\mathrm{H}_{3} \mathrm{TPP}^{+}}^{0}=\Delta_{\mathrm{o}}^{\mathrm{w}} \phi_{\mathrm{H}^{+}}^{0}+\frac{R T}{F} \ln \left(\frac{K_{\mathrm{a} 2}^{\mathrm{o}}}{K_{\mathrm{d}_{2}}^{\mathrm{w}} P_{\mathrm{H}_{2} \mathrm{TPP}}^{0}}\right)$

where $P_{\mathrm{H}_{2} \text { TPP }}^{0}$ is the standard partition coefficient of the neutral porphyrin defined by

$P_{\mathrm{H}_{2} \text { TPP }}^{0}=\frac{a_{\mathrm{H}_{2} \text { TPP }}^{0}}{a_{\mathrm{H}_{2} \text { TPP }}^{\mathrm{w}}}$

In Eq. (5) the terms $\Delta_{\mathrm{o}}^{\mathrm{w}} \phi_{\mathrm{H}^{+}}^{0}$ and $K_{\mathrm{a} 2}^{\mathrm{o}}$ have been determined experimentally but we need to evaluate the term $K_{\mathrm{a}_{2}}^{\mathrm{w}}$.

According to the Born solvation model, the Gibbs energy of solvation, is the sum of a term for the solvation of the equivalent neutral species and one for the ion-solvent contribution of the charge, $\Delta G_{\mathrm{IS}}$, given by [34]:
$\Delta G_{\mathrm{IS}}=-\frac{z^{2} e^{2} N_{\mathrm{A}}}{8 \pi \varepsilon_{0} r_{\mathrm{ion}}}\left(1-\frac{1}{\varepsilon_{\mathrm{r}}}\right)$

where $e$ is the elementary charge, $N_{\mathrm{A}}$ is the Avogadro's constant, $r$ is the molecular radius, $\varepsilon_{\mathrm{r}}$ is the relative permittivity, $z$ is the charge number and $\varepsilon_{0}$ is the vacuum permittivity. In this way, the standard partition coefficient for $\mathrm{H}_{3} \mathrm{TPP}^{+}$is related to the partition coefficient of the neutral $\mathrm{H}_{2}$ TPP by:

$$
\begin{aligned}
\ln P_{\mathrm{H}_{3} \mathrm{TPP}^{+}}^{0} & =-\frac{F \Delta_{\mathrm{o}}^{\mathrm{w}} \phi_{\mathrm{H}_{3} \mathrm{TPP}^{+}}^{0}}{R T}=-\frac{\Delta G_{\mathrm{tr}, \mathrm{H}_{3} \mathrm{TPP}^{+}}^{0, \mathrm{w}}}{R T} \\
& =-\frac{\Delta G_{\mathrm{tr}, \mathrm{H}_{2} \mathrm{TPP}}^{0, \mathrm{w} \rightarrow \mathrm{o}}}{R T}+\frac{\Delta G_{\mathrm{IS}}^{\mathrm{w}}-\Delta G_{\mathrm{IS}}^{0}}{R T} \\
& =\ln P_{\mathrm{H}_{2} \mathrm{TPP}}^{0}+\frac{e^{2} N_{\mathrm{A}}}{8 \pi \varepsilon_{0} r_{\mathrm{ion}} R T}\left(\frac{1}{\varepsilon_{\mathrm{r}}^{\mathrm{w}}}-\frac{1}{\varepsilon_{\mathrm{r}}^{\mathrm{o}}}\right)
\end{aligned}
$$

According to Eq. (8), the ratio $P_{\mathrm{H}_{3} \mathrm{TPP}^{+}}^{0} / P_{\mathrm{H}_{2} \text { TPP }}^{0}$ can be calculated as a function of the porphyrin radius. From the molecular structure, the diameters of $\mathrm{H}_{2}$ TPP are found to be $17.64 \AA$ and $10.16 \AA$ respectively.

$\ln \left(\frac{P_{\mathrm{H}_{3} \mathrm{TPP}^{+}}^{0}}{P_{\mathrm{H}_{2} \mathrm{TPP}}^{0}}\right)=\frac{e^{2} N_{\mathrm{A}}}{8 \pi \varepsilon_{0} r_{\mathrm{ion}} R T}\left(\frac{1}{\varepsilon_{\mathrm{r}}^{\mathrm{w}}}-\frac{1}{\varepsilon_{\mathrm{r}}^{\mathrm{o}}}\right)=-3.54$

i.e. a shift of $-8.8 \mathrm{~kJ} \mathrm{~mol}^{-1}$ for an average diameter of $1.3 \mathrm{~nm}$. Since according to Eq. (5), we also have

$\log \left(\frac{P_{\mathrm{H}_{3} \mathrm{TPP}}^{0}}{P_{\mathrm{H}_{2} \mathrm{TPP}}^{0}}\right)=\log P_{\mathrm{H}^{+}}^{0}+\mathrm{p} K_{\mathrm{a}_{2}}^{\mathrm{o}}-\mathrm{p} K_{\mathrm{a}_{2}}^{\mathrm{w}}$

we can calculate $K_{\mathrm{d}_{2}}^{\mathrm{w}}$. With $P_{\mathrm{H}^{+}}^{0}=5 \times 10^{-10}$ [35], we have $\mathrm{p} K_{\mathrm{d}_{2}}^{\mathrm{w}}=2.0$. As a result, the theoretical horizontal boundary line separating the monocation in the two adjacent phases is located at $\Delta_{\mathrm{o}}^{\mathrm{w}} \phi=-0.26 \mathrm{~V}$. It is important to notice that $\mathrm{p} K_{\mathrm{d}_{2}}^{\mathrm{w}}-\log P_{\mathrm{H}_{2} \text { TPP }}^{0}$ represents the apparent extraction $\mathrm{p} K_{\mathrm{a}}$. Indeed, to extract $\mathrm{H}_{2} \mathrm{TPP}$ from the organic phase, the $\mathrm{pH}$ of the aqueous phase should be smaller than the apparent $\mathrm{p} K_{\mathrm{a}}$ value, which can be estimated here at being equal to about -4.0 .

Line for $\mathrm{H}_{4} \mathrm{TPP}_{\mathrm{W}}^{2+} \rightleftarrows \mathrm{H}_{4} \mathrm{TPP}_{\mathrm{o}}^{2+}$

Again the Nernst equation for $\mathrm{H}_{4} \mathrm{TPP}^{2+}$ transfer reads

$\Delta_{\mathrm{o}}^{\mathrm{w}} \phi=\Delta_{\mathrm{o}}^{\mathrm{w}} \phi_{\mathrm{H}_{4} \mathrm{TPP}^{2+}}^{0}+\frac{R T}{2 F} \ln \left(\frac{a_{\mathrm{H}_{4} \mathrm{TPP}^{2+}}^{\mathrm{o}}}{a_{\mathrm{H}_{4} \mathrm{TPP}^{2+}}^{\mathrm{w}}}\right)$

with the standard transfer potential of $\mathrm{H}_{4} \mathrm{TPP}^{2+}$ given by

$\Delta_{\mathrm{o}}^{\mathrm{w}} \phi_{\mathrm{H}_{4} \mathrm{TPP}^{2+}}^{0}=\Delta_{\mathrm{o}}^{\mathrm{w}} \phi_{\mathrm{H}^{+}}^{0}+\frac{R T}{2 F} \ln \left(\frac{K_{\mathrm{a}_{1}}^{\mathrm{o}} K_{\mathrm{a}_{2}}^{\mathrm{o}}}{K_{\mathrm{a}_{1}}^{\mathrm{w}} K_{\mathrm{a}_{2}}^{\mathrm{w}} P_{\mathrm{H}_{2} \mathrm{TPP}}}\right)$

The acidity constants in the organic phase were determined by voltammetry, and as before we shall use the Born solvation model to estimate the aqueous $\mathrm{p} K_{\mathrm{a}}$ values.

Similarly, we have:

$\ln \left(\frac{P_{\mathrm{H}_{4} \mathrm{TPP}^{2+}}^{0}}{P_{\mathrm{H}_{2} \mathrm{TPP}}^{0}}\right)=\frac{4 e^{2} N_{\mathrm{A}}}{8 \pi \varepsilon_{0} r_{\mathrm{ion}} R T}\left(\frac{1}{\varepsilon_{\mathrm{r}}^{\mathrm{W}}}-\frac{1}{\varepsilon_{\mathrm{r}}^{\mathrm{o}}}\right)$

representing a shift of $-35.2 \mathrm{~kJ} \mathrm{~mol}^{-1}$ for a diameter of $1.3 \mathrm{~nm}$. By subtraction of Eqs. (13) and (9), we have

$\ln \left(\frac{P_{\mathrm{H}_{4} \mathrm{TPP}^{2+}}^{0}}{P_{\mathrm{H}_{3} \mathrm{TPP}^{+}}^{0}}\right)=\frac{3 e^{2} N_{\mathrm{A}}}{8 \pi \varepsilon_{0} r_{\mathrm{ion}} R T}\left(\frac{1}{\varepsilon_{\mathrm{r}}^{\mathrm{W}}}-\frac{1}{\varepsilon_{\mathrm{r}}^{\mathrm{o}}}\right)$

By comparing Eqs. (5) and (12), we have also

$\log \left(\frac{P_{\mathrm{H}_{4} \mathrm{TPP}^{2+}}^{0}}{P_{\mathrm{H}_{3} \mathrm{TPP}^{+}}^{0}}\right)=\log P_{\mathrm{H}^{+}}^{0}-\mathrm{p} K_{\mathrm{a}_{1}}^{\mathrm{o}}+\mathrm{p} K_{\mathrm{a}_{1}}^{\mathrm{w}}$ 
So we can calculate $K_{\mathrm{a}_{1}}^{\mathrm{w}}$. With $P_{\mathrm{H}^{+}}^{0}=5 \times 10^{-10}$, we have $\mathrm{p} K_{\mathrm{a}_{1}}^{\mathrm{w}}=2.0$. Since $\mathrm{p} K_{\mathrm{a}_{1}}^{\mathrm{w}}>\mathrm{p} K_{\mathrm{a}_{2}}^{\mathrm{w}}-\log P_{\mathrm{H}_{2} \text { TPP }}^{0} \approx-4.0$, we can conclude that the mono-acid does not exist in water. Indeed, the boundary line separating the dication between the two phases is located at $\Delta_{\mathrm{o}}^{\mathrm{w}} \phi=0.004 \mathrm{~V}$, i.e. at more positive values than for the monocation.

Assisted proton transfer reactions

Line for $\mathrm{H}_{2} \mathrm{TPP}_{\mathrm{o}}+\mathrm{H}_{\mathrm{W}}^{+} \rightleftarrows \mathrm{H}_{3} \mathrm{TPP}_{\mathrm{o}}^{+}$

The Nernst equation for proton transfer gives

$\Delta_{\mathrm{o}}^{\mathrm{w}} \phi=\Delta_{\mathrm{o}}^{\mathrm{w}} \phi_{\mathrm{H}^{+}}^{0}+\frac{R T}{F} \ln \left(\frac{K_{\mathrm{a}_{2}}^{\mathrm{o}}}{a_{\mathrm{H}^{+}}^{\mathrm{w}}}\right)+\frac{R T}{F} \ln \left(\frac{a_{\mathrm{H}_{3} \mathrm{TPP}^{+}}^{\mathrm{o}}}{a_{\mathrm{H}_{2} \mathrm{TPP}}^{\mathrm{T}}}\right)$

The borderline of the partition diagram for the equiconcentration of $\mathrm{H}_{2}$ TPP and $\mathrm{H}_{3} \mathrm{TPP}^{+}$in the organic phase is then

$\Delta_{\mathrm{o}}^{\mathrm{w}} \phi=\Delta_{\mathrm{o}}^{\mathrm{w}} \phi_{\mathrm{H}^{+}}^{0}+\frac{R T}{F} \ln K_{\mathrm{a}_{2}}^{\mathrm{o}}+0.06 \mathrm{pH}$

Line for $\mathrm{H}_{3} \mathrm{TPP}_{\mathrm{o}}^{+}+\mathrm{H}_{\mathrm{W}}^{+} \rightleftarrows \mathrm{H}_{4} \mathrm{TPP}_{\mathrm{o}}^{2+}$

In this case, the Nernst equation for proton transfer gives

$\Delta_{\mathrm{o}}^{\mathrm{w}} \phi=\Delta_{\mathrm{o}}^{\mathrm{w}} \phi_{\mathrm{H}^{+}}^{0}+\frac{R T}{F} \ln \left(\frac{K_{\mathrm{a}_{1}}^{\mathrm{o}}}{a_{\mathrm{H}^{+}}^{\mathrm{w}}}\right)+\frac{R T}{F} \ln \left(\frac{a_{\mathrm{H}_{4} \mathrm{TPP}^{2+}}^{\mathrm{o}}}{a_{\mathrm{H}_{3} \mathrm{TPP}^{+}}^{\mathrm{w}}}\right)$

and the borderline for the equiconcentration of $\mathrm{H}_{3} \mathrm{TPP}^{+}$and $\mathrm{H}_{4} \mathrm{TPP}^{2+}$ in the organic phase is then

$\Delta_{\mathrm{o}}^{\mathrm{w}} \phi=\Delta_{\mathrm{o}}^{\mathrm{w}} \phi_{\mathrm{H}^{+}}^{0}+\frac{R T}{F} \ln K_{\mathrm{a}_{1}}^{\mathrm{o}}+0.06 \mathrm{pH}$

Line for $\mathrm{H}_{3} \mathrm{TPP}_{\mathrm{o}}^{+}+\mathrm{H}_{\mathrm{W}}^{+} \rightleftarrows \mathrm{H}_{4} \mathrm{TPP}_{\mathrm{W}}^{2+}$

We start here from the Nernst equation for the mono-acid given by Eq. (4)

$$
\begin{aligned}
\Delta_{\mathrm{o}}^{\mathrm{w}} \phi & =\Delta_{\mathrm{o}}^{\mathrm{w}} \phi_{\mathrm{H}_{3} \mathrm{TPP}^{+}}^{0}+\frac{R T}{F} \ln \left(\frac{a_{\mathrm{H}_{3} \mathrm{TPP}^{+}}^{\mathrm{o}}}{a_{\mathrm{H}_{3} \mathrm{TPP}^{+}}^{\mathrm{w}}}\right) \\
& =\Delta_{\mathrm{o}}^{\mathrm{w}} \phi_{\mathrm{H}_{3} \mathrm{TPP}^{+}}^{0}+\frac{R T}{F} \ln \left(\frac{a_{\mathrm{H}_{3} \mathrm{TPP}^{+}}^{\mathrm{o}} a_{\mathrm{H}^{+}}^{\mathrm{w}}}{K_{\mathrm{a}_{2}}^{\mathrm{w}} a_{\mathrm{H}_{4} \mathrm{TPP}^{2+}}^{\mathrm{w}}}\right)
\end{aligned}
$$

The borderline for the equiconcentration of $\mathrm{H}_{3} \mathrm{TPP}^{+}$in the organic phase and $\mathrm{H}_{4} \mathrm{TPP}^{2+}$ in water is then

$\Delta_{\mathrm{o}}^{\mathrm{w}} \phi==\Delta_{\mathrm{o}}^{\mathrm{w}} \phi_{\mathrm{H}_{3} \mathrm{TPP}^{+}}^{0}-\frac{R T}{F} \ln K_{\mathrm{a}_{1}}^{\mathrm{w}}-0.06 \mathrm{pH}$

Line for $\mathrm{H}_{2} \mathrm{TPP}_{\mathrm{o}}+2 \mathrm{H}_{\mathrm{w}}^{+} \rightleftarrows \mathrm{H}_{4} \mathrm{TPP}_{\mathrm{w}}^{2+}$

Given that the aqueous form of the mono-acid does not exist, the frontier separating the predominance regions of $\mathrm{H}_{2} \mathrm{TPP}_{(\mathrm{o})}$ and $\mathrm{H}_{4} \mathrm{TPP}_{(\mathrm{w})}^{2+}$ is calculated from the two aqueous acidity constants previously estimated and the partition coefficient of the neutral freebase, as follows:

$K_{\mathrm{a}_{1}}^{\mathrm{w}} K_{\mathrm{a}_{2}}^{\mathrm{w}}=\frac{\left(a_{\mathrm{H}^{+}}^{\mathrm{w}}\right)^{2} a_{\mathrm{H}_{2} \mathrm{TPP}}^{\mathrm{w}}}{a_{\mathrm{H}_{4} \mathrm{TPP}^{2+}}^{\mathrm{w}}}=\frac{\left(a_{\mathrm{H}^{+}}^{\mathrm{w}}\right)^{2} a_{\mathrm{H}_{2} \mathrm{TPP}}^{\mathrm{o}}}{a_{\mathrm{H}_{4} \mathrm{TPP}^{2+}}^{\mathrm{w}} P_{\mathrm{H}_{2} \mathrm{TPP}}^{0}}$

which can be finally expressed as:

$\mathrm{pH}=\frac{1}{2}\left(\mathrm{p} K_{\mathrm{a}_{1}}^{\mathrm{w}}+\mathrm{p} K_{\mathrm{a}_{2}}^{\mathrm{w}}-\log P_{\mathrm{H}_{2} \text { TPP }}^{0}\right)$

\begin{tabular}{|c|c|}
\hline $\mathrm{H}_{2} \mathrm{TPP}_{\mathrm{o}} / \mathrm{H}_{3} \mathrm{TPP}_{\mathrm{o}}^{+}$ & $\Delta_{\mathrm{o}}^{\mathrm{w}} \phi=0.55+0.059 \cdot(\mathrm{pH}-9.8)$ \\
\hline $\mathrm{H}_{3} \mathrm{TPP}_{\mathrm{o}}^{+} / \mathrm{H}_{4} \mathrm{TPP}_{\mathrm{o}}^{2+}$ & $\Delta_{\mathrm{o}}^{\mathrm{w}} \phi=0.55+0.059 \cdot(\mathrm{pH}-6)$ \\
\hline $\mathrm{H}_{4} \mathrm{TPP}_{\mathrm{o}}^{2+} / \mathrm{H}_{4} \mathrm{TPP}_{\mathrm{w}}^{2+}$ & $\Delta_{\mathrm{o}}^{\mathrm{w}} \phi_{\mathrm{H}_{4} \mathrm{TPP}^{2+}}^{0}=0.55+\frac{0.059}{2} \cdot(2+1.3-6-9.8-6)=0.004 \mathrm{~V}$ \\
\hline $\mathrm{H}_{3} \mathrm{TPP}_{\mathrm{o}}^{+} / \mathrm{H}_{4} \mathrm{TPP}_{\mathrm{w}}^{2+}$ & $\Delta_{\mathrm{o}}^{\mathrm{w}} \phi=-0.31-0.059 \cdot(-1.3+\mathrm{pH})$ \\
\hline $\mathrm{H}_{2} \mathrm{TPP}_{\mathrm{o}} / \mathrm{H}_{4} \mathrm{TPP}_{\mathrm{w}}^{2+}$ & $\mathrm{pH}=\frac{1}{2}(1.3+2-6)=-1.35$ \\
\hline
\end{tabular}

Table 1

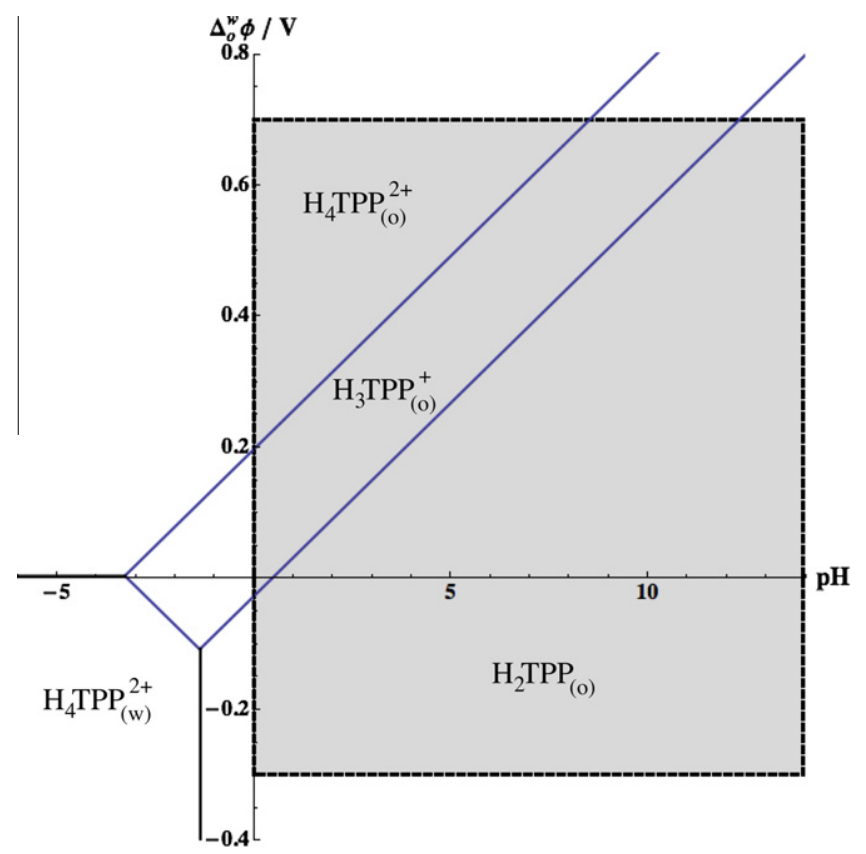

Fig. 3. Ionic partition diagram of $\mathrm{H}_{2} \mathrm{TPP}$ at the water|1,2-DCE interface. The shadowed area represents the attainable conditions in a typical experiment.

In summary, the partition diagram of the $\mathrm{H}_{2}$ TPP can be summarized by the equations given in Table 1 and illustrated in Fig. 3.

\section{Conclusion}

The Born solvation model provides a self-consistent extra-thermodynamic approximation to calculate the ionic partition diagram of $\mathrm{H}_{2}$ TPP from the assisted proton transfer voltammetric data. In particular, it provides an indirect method to estimate the acidity constants in water that cannot be measured experimentally.

The partition diagram of $\mathrm{H}_{2}$ TPP also illustrates why the monoprotonated form in the organic phase has been difficult to observe, as its zone of existence is rather limited. By ion-transfer voltammetry, one travels along a vertical line when the aqueous $\mathrm{pH}$ is fixed and the two protonation reactions are separated by about $200 \mathrm{mV}$.

When doing a biphasic $\mathrm{pH}$ titration, i.e. changing the aqueous $\mathrm{pH}$ and monitor the two phases by UV-vis, it is very difficult to keep the polarisation constant in the absence of a potentiostatic control.

Free-base porphyrins have been recently shown to act as catalysts for oxygen reduction [29,36], and the present methodology is useful to determine the ionic partition diagrams of these molecules to better understand their catalytic role upon their protonation.

\section{Acknowledgements}

This work was supported by EPFL, the Swiss National Science Foundation (FNRS 200020-116588) and European COST Action (D36/007/06).

\section{References}

[1] J. Simplicio, Biochemistry 11 (1972) 2525-2528.

[2] S. Mazumdar, O.K. Medhi, N. Kannadaguili, S. Mitra, J. Chem. Soc. Dalton (1989) 1003-1005.

[3] V.S. Chirvony, A. Van Hoek, V.A. Galievsky, I.V. Sazanovich, T.J. Schaafsma, D. Holten, J. Phys. Chem. B 104 (2000) 9909-9917.

[4] A. Stone, E.B. Fleischer, J. Am. Chem. Soc. 90 (1968) 2735-2748.

[5] W.S. Sheldrick, J. Chem. Soc. Perkin Trans. 2 (1976) 453-456. 
[6] E. Cetinkaya, A.W. Johnson, M.F. Lappert, G.M. McLaughlin, K.W. Muir, J. Chem. Soc. Dalton (1974) 1236-1243.

[7] B. Cheng, O.Q. Munro, H.M. Marques, W.R. Scheidt, J. Am. Chem. Soc. 119 (1997) 10732-10742.

[8] L.D. Sparks, C.J. Medforth, M.S. Park, J.R. Chamberlain, M.R. Ondrias, M.O. Senge, K.M. Smith, J.A. Shelntt, J. Am. Chem. Soc. 115 (1993) 581-592.

[9] C.J. Medforth, M.O. Senge, K.M. Smith, L.D. Sparks, J.A. Shelnutt, J. Am. Chem Soc. 114 (1992) 9859-9869.

[10] A.H. Corwin, A.B. Chivvis, R.W. Poor, D.G. Whitten, E.W. Baker, J. Am. Chem. Soc. 90 (1968) 6577-6583.

[11] A. Hofmanova, L.Q. Hung, W. Khalil, J. Electroanal. Chem. 135 (1982) 257-264.

[12] N. Kozlov Yu, J. Koryta, Anal. Lett. 16 (1983) 255-263.

[13] E. Wang, Y. Liu, J. Electroanal. Chem. 214 (1986) 459-464.

[14] Z. Yoshida, H. Freisher, J. Electroanal. Chem. 162 (1984) 307-319.

15] Y. Liu, E. Wang, J. Electroanal. Chem. 234 (1987) 85-92.

[16] D. Homolka, K. Holub, V. Marecek, J. Electroanal. Chem. 138 (1982) 29-36.

[17] J. Koryta, P. Vanysek, M. Brezina, J. Electroanal. Chem. 75 (1977) 211-228.

[18] J. Koryta, P. Vanysek, M. Brezina, J. Electroanal. Chem. 67 (1976) 263-266.

[19] Z. Samec, V. Marecek, J. Weber, J. Electroanal. Chem. 100 (1979) 841-852.

[20] Z. Samec, V. Marecek, J. Koryta, M.W. Khalil, J. Electroanal. Chem. 83 (1977) 393-397.

[21] F. Reymond, G. Steyaert, A. Pagliara, P.A. Carrupt, B. Testa, H. Girault, Helv. Chim. Acta 79 (1996) 1651-1669.

[22] F. Reymond, G. Steyaert, P.A. Carrupt, B. Testa, H.H. Girault, Helv. Chim. Acta 79 (1996) 101-117.
[23] F. Reymond, G. Steyaert, P.A. Carrupt, B. Testa, H. Girault, J. Am. Chem. Soc. 118 (1996) 11951-11957.

[24] V. Gobry, S. Ulmeanu, F. Reymond, G. Bouchard, P. Carrupt, B. Testa, H. Girault, J. Am. Chem. Soc. 123 (2001) 10684-10690.

[25] X.H. Xia, W.D. Su, S.M. Zhou, J. Electroanal. Chem. 324 (1992) 59-68.

[26] T. Osakai, K. Muto, J. Electroanal. Chem. 496 (2001) 95-102.

[27] H. Nagatani, H. Watarai, Anal. Chem. 68 (1996) 1250-1253.

[28] B. Su, F. Li, R. Partovi-Nia, C. Gros, J.M. Barbe, Z. Samec, H.H. Girault, Chem. Commun. (2008) 5037-5038.

[29] A. Trojanek, J. Langmaier, B. Su, H.H. Girault, Z. Samec, Electrochem. Commun. 11 (2009) 1940-1943.

[30] J.W. Buchler, The Porphyrins, Academic Press, New York, 1978.

[31] M.H. Abraham, A.F. Danil de Namor, J. Chem. Soc., Faraday Trans. 72 (1976) 955-962.

[32] H. Matsuda, Y. Yamada, K. Kanamori, Y. Kudo, Y. Takeda, Bull. Chem. Soc. Jap. 64 (1991) 1497-1508.

[33] M. Pourbaix, Atlas d'Equilibres Electrochimiques, Gauthier-Villars, Paris, 1963.

[34] H. Girault, Electrochime Physique et Analytique, Presses Polytechniques et Universitaires Romandes, Lausanne, 2007.

[35] A.J. Olaya, M.A. Méndez, F. Cortes-Salazar, H.H. Girault, J. Electroanal. Chem. 644 (2010) 60-66.

[36] I. Hatay, B. Su, M.A. Mendez, C. Corminboeuf, T. Khoury, C.P. Gros, M. Bourdillon, M. Meyer, J.-M. Barbe, M. Ersoz, S. Zalis, Z. Samec, H.H. Girault, J. Am. Chem. Soc. 132 (2010) 13733-13741. 